\title{
EFEECTIVENES OF PQ4R METACOGNITIVE STRATEGY BASED READING LEARNING MODELS IN JUNIOR HIGH SCHOOL
}

\author{
Eri Sarimanah \\ Indonesian Language and Literature Study Program FKIP Pakuan University, Indonesia \\ sarimanah.herty@gmail.com
}

\begin{abstract}
The objective of research is to find out the efectivenes of metacognitive Preview, Question, Read, Reflect, Recite, Review (PQ4R) strategy based reading learning model to improve SMP students' reading ability. The method applied in this study is research and development by using both qualitative and quantitative approaches. The research result shows that the ideal learning model needed by the students is metacognitive PQ4R strategy based reading learning model. Structurally, this learning model is viable, relevant, and suitable with the principles of learning model development, both from substantial view and the structural model. Based on the trial result with experimental research design (experimental and control groups), metacognitive PQ4R strategy based reading learning model is effective to be used to improve SMP students' reading ability. Even the learning outcome is better than the reading class done by the teacher who does not use metacognitive PQ4R strategy. learning metacognitive reading strategies based PQ4R junior high school students are more effective than learning to read that teachers without the use of metacognitive strategies PQ4R with the calculation results of test of $5.975 t$ test is greater than table 1.67. So it can be concluded that the learning model based reading metacognitive strategies PQ4R effective and fit for use in secondary schools.
\end{abstract}

Keywords: instructional models; PQ4R metacognitive strategies; reading skills.

Reading plays a very important role in human life. Reading is not limited by space and time. Various information about science, technology, art and culture can be obtained by reading. The paramount role of reading as referred to above must be balanced with students activity or hobby in reading. Students do not fully get the results of reading, if they are not accustomed to using the method of reading, and have not even used to reading independently (Damayanti, 2003: 5). In understanding reading materials, students are generally still limited by its literal meaning. Students are rarely encouraged to develop inferential, evaluative, dan appreciative understanding.

Chapman and King stated that the main role of a teacher is to cater and sustain students' willingness to learn and a willingness to read so that it becomes an internal force for development. When students have had the will, they are motivated, they become readers who are able to organize themselves, be eloquent, and responsible (Chapman, 2003: 5).

The model which provides a fun learning experience and able to create autonomous learners is needed (Brown, 2001: 131). As the outcome of the process, the learner can assess reading by monitoring the process of reading and evaluating the progress of reading (McNeil, 1984: 83). Such activities are metacognitive activity.

The learning model is a conceptual framework or pattern which is used as a guide in planning and realizing a learning process. Learning model for reading is a pattern that is used in the activity of learning to read so that students who really responds to 
the activity got the message. Reading quality of a person's is determined by how he understands the reading materials read.

Finocchiaro (1989: 113) stated "There are three factors that influence a person's reading comprehension, namely intellectual ability, extensive knowledge, and reading strategies. To be able to read properly, one must have the intellectual capability, extensive knowledge, and the right strategy.

A person with reading habit is usually enthusiastic when being offered a reading materials. They are enthusiastic, active, and creative to immediately find out the information in the reading material. In addition, they will review what they have read and tried to find out what has not been understood by using prior knowledge (eg. about syntax and vocabulary) and other skills to understand the texts in the reading material. Understanding occurs through the application of strategy and skill. The ability to integrate both will direct a person to active reading.

\section{Metacognitive Strategy}

There are three principles of psychology in the process of reading comprehension strategies which include: (1) the importance of the initial knowledge of learners in the acquisition of new information, (2) the level of understanding of the text which is achieved in a material, and (3) the organization of information to help the longterm memory.

Based on the observation of the stages of learning to read as proposed by experts, the experts initially pay more attention to the pre and post reading activity. However, thanks to the assessment of the professional reader reading process, in the end they also considered that during reading activity is essential in designing reading learning (Sarimanah, 2008: 39).

Metacognitive strategies refers to a way to raise awareness about the thought process in the ongoing learning. If this awareness is realized, then one can start thinking about designing, monitoring and assessing what he learned. If this strategy is applied in reading activities, it is believed to successfully increase understanding of reading materials.

\section{PQ4R Metacognitive Strategy}

PQ4R is a method of reading in metacognitive strategies. As stated by Donndelinger in Israel, et al. (2005: 242) metacognitive reading involves the following steps: Previewing, Questioning, Reading, Reflecting, Reciting, and Reviewing (PQ4R). Also argued by Seng (2003: 419) that PQ4R is a method in metacognitive strategies. PQ4R stands for previewing, questioning, reading, reflecting, reciting, and reviewing which will encourage students to preview, ask questions, read, reflect, recite, and repeat the reading material to be understood and mastered in their own way.

Whereas the steps of reading learning activities read which applies metacognitive strategies of Previewing, Questioning, Reading, Reflecting, Reciting, Reviewing are grouped on stage pre, in, and post reading as shown in the following table.

Tabel 1. PQ4R Metacognitive Strategy in Reading Learning

\begin{tabular}{llll}
\hline $\begin{array}{l}\text { Metacognitive } \\
\text { Strategy }\end{array}$ & Phase & Steps & Activity \\
\hline
\end{tabular}




\begin{tabular}{|c|c|c|c|}
\hline Planning & $\begin{array}{l}\text { Pre-reading: } \\
\text { Reading focus }\end{array}$ & Question & $\begin{array}{l}\text { - } \text { Reviewing the reading } \\
\text { material in general } \\
\text { - } \text { Connecting the things that } \\
\text { are already known } \\
\text { - } \text { Formulating objectives } \\
\text { - } \text { Directing attention } \\
\text { - Identifying reading } \\
\text { material } \\
\text { - Predicting the content of } \\
\text { reading } \\
\text { - Asking question } \\
\text { by looking at the titles, } \\
\text { subtitles, paragraphs as } \\
\text { reference }\end{array}$ \\
\hline Implementation & $\begin{array}{l}\text { Reading: } \\
\text { Reading } \\
\text { arrangement and } \\
\text { implementation }\end{array}$ & Read & $\begin{array}{l}\text { - Through the process of } \\
\text { reading: } \\
\text { - Trying to find information } \\
\text { on reading material } \\
\text { - } \text { optimally organizing } \\
\text { reading material } \\
\text { - Finding out if the } \\
\text { objectives / questions is } \\
\text { already achieved, was } \\
\text { found in the literature } \\
\text { - Monitoring reading }\end{array}$ \\
\hline & & Reflect & $\begin{array}{l}\text { - Linking information with } \\
\text { things that are already } \\
\text { known } \\
\text { - Solving the contradiction of } \\
\text { the information presented } \\
\text { - Finding answer to questions }\end{array}$ \\
\hline Evaluasi & $\begin{array}{l}\text { Pascabaca: } \\
\text { Menilai } \\
\text { membaca }\end{array}$ & Review & $\begin{array}{l}\text { - Evaluating the results of } \\
\text { reading } \\
\text { - Re-reading } \\
\text { - Creating summary } \\
\text { - Explaining the results of } \\
\text { reading with their own } \\
\text { words } \\
\text { - Conducting Simulation and } \\
\text { discussion }\end{array}$ \\
\hline
\end{tabular}

\section{METHOD}

The method used is the Research and Development with qualitative and quantitative approaches. More details are shown in the following table.

Table 2. 


\begin{tabular}{|c|c|c|c|}
\hline Activity & Target & Outcome & Method \\
\hline $\begin{array}{l}\text { Analysis of syllabus } \\
\text { document and lesson } \\
\text { plans used in SMPN } \\
3 \text { Bogor and } \\
\text { observation of } \\
\text { teaching and learning }\end{array}$ & $\begin{array}{l}\text { Providing } \\
\text { information } \\
\text { about the } \\
\text { components of } \\
\text { learning and } \\
\text { reading activities } \\
\text { with the } \\
\text { characteristics of } \\
\text { the learning } \\
\text { model available } \\
\text { Synthesizing } \\
\text { information on } \\
\text { the steps needed } \\
\text { for reading from } \\
\text { teachers, and } \\
\text { students. }\end{array}$ & $\begin{array}{l}\text { a. List of learning } \\
\text { components, needs } \\
\text { analysis } \\
\text { instrument, the } \\
\text { characteristics of } \\
\text { the model that has } \\
\text { been used } \\
\text { b. Perceptions of } \\
\text { models available } \\
\text { and which will be } \\
\text { developed }\end{array}$ & $\begin{array}{l}\text { Document } \\
\text { Observation }\end{array}$ \\
\hline
\end{tabular}

\section{Model Design Preparation \& Development Stage}

\begin{tabular}{|c|c|c|c|}
\hline Activity & Target & Outcome & Method \\
\hline $\begin{array}{l}\text { Developing a model } \\
\text { framework by } \\
\text { identifying } \\
\text { objectives, materials, } \\
\text { strategies, media, } \\
\text { evaluation }\end{array}$ & $\begin{array}{l}\text { Preparing a list of } \\
\text { components of } \\
\text { learning and teaching } \\
\text { model inputs that are } \\
\text { ready to be } \\
\text { developed }\end{array}$ & $\begin{array}{l}\text { Preparing List of the } \\
\text { conditions of learning } \\
\text { and teaching model } \\
\text { framework as well as } \\
\text { qualitative information } \\
\text { on the feasibility of } \\
\text { implementative study } \\
\text { model }\end{array}$ & $\begin{array}{l}\text { Questioner } \\
\text { Observation } \\
\text { Interview }\end{array}$ \\
\hline $\begin{array}{l}\text { Developing model } \\
\text { framework into draft } \\
\text { and assessment } \\
\text { questionnaire and } \\
\text { observation } \\
\text { guidelines of teaching } \\
\text { models for testing } \\
\text { and expert validation }\end{array}$ & $\begin{array}{l}\text { Providing draft, } \\
\text { assessment } \\
\text { questionnaires and } \\
\text { observation sheets of } \\
\text { learning model }\end{array}$ & $\begin{array}{l}\text { Draft learning model } \\
\text { that is ready for field } \\
\text { tests, questionnaire } \\
\text { assessment and } \\
\text { observation guidelines }\end{array}$ & \\
\hline
\end{tabular}

\begin{tabular}{|c|c|c|c|}
\hline \multicolumn{4}{|c|}{ Preliminary Test Stage and Model Revision } \\
\hline Activity & Target & Outcome & Method \\
\hline $\begin{array}{l}\text { Using individual } \\
\text { students, small } \\
\text { groups of students. }\end{array}$ & $\begin{array}{l}\text { Obtain qualitative } \\
\text { information about } \\
\text { the learning model } \\
\text { developed }\end{array}$ & $\begin{array}{l}\text { Qualitative information } \\
\text { from questionnaire is } \\
\text { revised for learning } \\
\text { models for testing }\end{array}$ & Experiment \\
\hline $\begin{array}{l}\text { Conducting Focus } \\
\text { Group with MGMP }\end{array}$ & $\begin{array}{l}\text { Obtain qualitative } \\
\text { information relating } \\
\text { to the models } \\
\text { developed }\end{array}$ & $\begin{array}{l}\text { Qualitative information } \\
\text { about the learning } \\
\text { model based reading } \\
\text { PQ4R metacognitive } \\
\text { strategies }\end{array}$ & $\begin{array}{l}\text { Focus Group } \\
\text { Discussion }\end{array}$ \\
\hline
\end{tabular}

\begin{tabular}{l}
$\begin{array}{l}\text { Model Effectiveness Testing Stage } \\
\text { And Revision of Final Product }\end{array}$ \\
\hline Target \\
\hline
\end{tabular}




\begin{tabular}{llll}
\hline $\begin{array}{l}\text { Using a model of } \\
\text { learning in the group } \\
\text { expanded with the } \\
\text { experimental } \\
\text { observations with all } \\
\text { students experiences } \\
\text { that arise during the } \\
\text { use of such model }\end{array}$ & $\begin{array}{l}\text { Expanding the } \\
\text { information in order } \\
\text { to know the results } \\
\text { of pre and post-test } \\
\text { and the data on the } \\
\text { experience of } \\
\text { students using such } \\
\text { learning model }\end{array}$ & $\begin{array}{l}\text { Data from pre-test and } \\
\text { post-test experiment, } \\
\text { and the results of } \\
\text { observation }\end{array}$ & Experiment \\
$\begin{array}{l}\text { Reviewing the } \\
\text { implementation of the } \\
\text { PQ4R metacognitive } \\
\text { strategies based } \\
\text { reading learning } \\
\text { model in the }\end{array}$ & $\begin{array}{l}\text { Gathering } \\
\text { information about } \\
\text { the improvement of } \\
\text { the learning model } \\
\text { developed and } \\
\text { effectiveness of the } \\
\text { model }\end{array}$ & $\begin{array}{l}\text { Qualitative information } \\
\text { about the quality of } \\
\text { learning models, } \\
\text { perceptions of teachers } \\
\text { and students of the } \\
\text { models and } \\
\text { quantitative } \\
\text { information about the } \\
\text { effectiveness of the } \\
\text { learning model }\end{array}$ & Questioner \\
\hline
\end{tabular}

In collecting and gathering data on existing conditions, descriptive method is used. Evaluative methods, are used to evaluate the process of testing the development of a product. Experimental method is used to test the efficacy of the resulting product randomly. Comparison of the experimental results in both groups can indicate the efficacy of the product.

Model Development

Development Mechanism of the learning model in this study are described below.

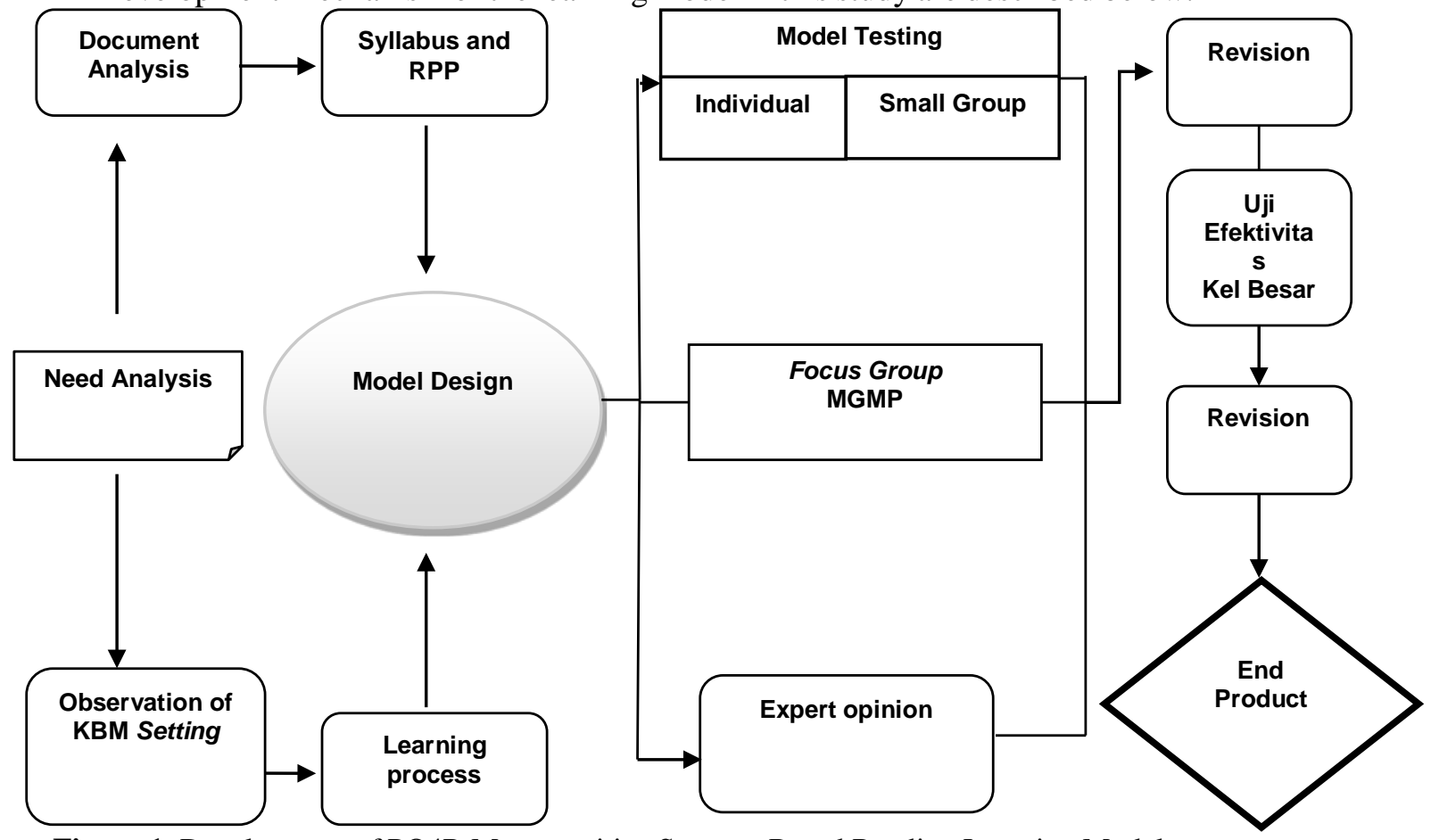

Figure 1. Development of PQ4R Metacognitive Strategy Based Reading Learning Model 


\section{RESULT}

\section{Effectiveness of PQ4R Metacognitive Strategy Based Reading Learning Model}

The metacognitive strategy based reading learning model prepared has been validated and has undergone a series of research activities of ongoing process to obtain a final product of tested models. Such learning is preceded with pre-test and ended with post-test activities. After the t-test requirements are met by the results of the data normality and homogeneity test, test-t that the results show that the pretest and posttest differ significantly. The average (mean) pretest was 50.055 (standard deviation 6.5656), while the average is 78.138 posttest mean (standard deviation 8.9695). The results of the t-test of 22.922 is greater than t table of 1.994. This indicates that the learning model based reading metacognitive strategies PQ4R effective in increasing the average score of students' ability to comprehend reading material.

Afterward, evaluation results of assessor (expert) demonstrated the feasibility of PQ4R metacognitive strategies based reading learning model to be used in secondary schools. The reading learning model based on PQ4R metacognitive strategy which have been tested in theory has met the entire component model proposed by the experts. To corroborate the opinion or the results of the study, the researchers conducted focus groups with Indonesian Language teachers in Bogor city which belongs to MGMP (Council of Subject Teacher). metacognitive based learning model is practical, clear and systematic to use in learning stages which allows anyone who wants to improve the ability to understand reading materials to apply it.

Reliability of agreement between intrareliability assessors are based on Kappa Coefficient calculation of 0.75 with almost perfect interpretation. Thus, it can be concluded that that the reading learning model based on PQ4R metacognitive strategies for secondary school students have been effective, adequate and fit for use as a model for learning to read.

\section{DISCUSSION}

Based on a series of studies conducted at study location, there are findings and information obtained relating to the reading learning model. It includes, among others, the perception of users (teachers and students) to the model of learning to read, the needs of students and teachers on reading methods, efforts to develop students' ability to understand the reading material. Nevertheless, there are a number of factors supporting and accompanying the development and implementation of the results obtained. Limitations of the study with respect to this research is not conducted in a wider scale to reach more schools. The research mechanism also follows the schedule provided for Indonesian subjects in the study location.

Other findings are related to the learning model used to read in school. So far students are not aware of the methods and strategies of reading. Those students read as an activities only after being given reading material or ordered by teachers to read. They do not know how to read properly. After reading they were asked to fill a number of questions by teachers. Question from the reading material is just about any literal understanding. In addition, there was no reading difficulties caused by factors such as dyslexia or reading failure due to brain damage the reader. 
After research and testing of learning model based reading metacognitive strategies, students expressed his opinion that they feel enlightened when they are able to understand the stages of reading and how to enjoy reading. They started reading with the planning process in reading stages. They involve themselves mentally to active interaction with the text they read, associated with schemata owned. Who has never been to exercise control over his reading comprehension, through PQ4R metacognitive strategies students perform monitoring and control over his reading comprehension. At the end of their activities, they will evaluate the results of reading.

The metacognitive strategy based reading learning model bases is perceived to have given a new feel and a new experience in reading. In general, students who has known about the the methods and strategies of reading and who try to implement the strategy at the reading material and their new situation become fond of reading and even understand the reading material. Presumably if it is beneficial and may improve students reading skills, it is reasonable that the reading learning model became one of the alternatives that can be used by the school and educational policy makers as to the importance of the application of the metacognitive strategies based reading learning model in secondary schools.

There are four implications of the results of this research in learning to read. First, PQ4R metacognitive strategies based reading learning model is one alternative model that can be used to assist students in overcoming various difficulties in improving their reading skills. Therefore, the development of this model can be tested on three other language skills, namely listening, speaking, and writing.

Second, metacognitive strategy based reading learning model developed has a principle that requires teachers to motivate students to be kept informed of reading, so that in the end the students were able to communicate the results read. Therefore, in the other study would be attempted application of metacognitive strategies.

Third, by using metacognitive strategy based reading learning model, learning process will be more dynamic, because it actively involves students in search of information from the text. The dynamic learning process is the desire of all teachers. The teachers in the field can try metacognitive strategies based learning model.

Fourth, metacognitive strategies based learning model is in principle is an attempt to change the paradigm of learning that has been teacher oriented to become student oriented learning. In addition, pedagogically, this study may have implications on the role and function of the teacher as a facilitator, mentor, and at the same evaluator. Therefore, at every level of education presumably it is proper to use metacognitive strategies to maximize the role and function of teachers to enable students to learn.

\section{CONCLUSION}

The PQ4R metacognitive strategies based reading learning model developed in this study is a conceptual framework which contains propositions as a guide for teachers to design and implement learning activities based on PQ4R metacognitive strategies for junior high school students.

From the the effectiveness of the learning model that is applied to the design of experimental studies with control class it may be concluded that reading learning model based on PQ4R metacognitive strategies in junior high school students are 
more effective than reading learning conducted teachers without the use of PQ4R metacognitive strategies with the calculation results of test of t test of 5.975 greater than t table 1.67. Based on these data, it can be concluded that the reading learning model based on PQ4R metacognitive strategies is effective and fit for use in secondary schools.

\section{REFERENCES}

Brown, H. Douglas. Teaching by Principles: An Interactive Approach to Language Pedagogy. San Fransisco: San Fransisco State University, 2001.

Chapman, Carolyn dan Rita King. Differentiated Instructional Strategies for Reading in the Content Areas. California: Corwin Press, Inc., 2003.

Damayanti, Vismaia. Mendamba Indonesia yang Literat. Bandung: Jurusan Pendidikan Bahasa dan Sastra Indonesia FPBS UPI Pres, 2003.

Finocchiaro, Marry. English As A Second/Foreign Language: From Theory to Practice. New Jersey: Printice-Hall Regents,1989.

Israel, Susan E., Cathy Collins Block, dan Kathryn L. Bauserman. Metacognition in Literacy Learning. New Jersey: Lawrence Erlbaum Associates Publisher, 2005.

McNeil, John D. Reading Comprehension. Boston: Scott, Foresman Company, 1984.

Ong Seng, Tan. Educational Psychology: A Practitioner Researcher Approach. Singapura: Thomson, 2003.

Sarimanah, Eri. "Peningkatan Kemampuan Pemahaman Bacaan melalui Strategi Metakognitif PQ4R.” Tesis Program Studi Pendidikan Bahasa Program Pascasarjana Universitas Negeri Jakarta, 2008. 